\title{
TEMPERAMEN, INTERAKSI IBU-REMAJA, DAN KECERDASAN EMOSI REMAJA PADA KELUARGA DENGAN IBU BEKERJA DI PERDESAAN
}

\author{
Nadya Ramadhianti ${ }^{\left.{ }^{*}\right)}$, Alfiasari ${ }^{1}$ \\ 1Departemen IImu Keluarga dan Konsumen, Fakultas Ekologi Manusia, Institut Pertanian Bogor, Bogor 16680, \\ Indonesia \\ *)E-mail: vnaddya@gmail.com
}

\begin{abstract}
Abstrak
Penelitian ini bertujuan menganalisis pengaruh karakteristik remaja dan karakteristik keluarga terhadap interaksi ibu-remaja pada keluarga remaja dengan ibu bekerja di perdesaan serta menganailsis pengaruh karakteristik remaja, karakteristik keluarga, dan interaksi ibu-remaja terhadap kecerdasan emosi remaja pada keluarga remaja dengan ibu bekerja di perdesaan. Penelitian ini dilaksanakan di Ciampea, Kabupaten Bogor, yang dipilih secara sengaja dengan pertimbangan sebagai wilayah perdesaan dan lokasi pengembangan industri non-farm dengan banyaknya sentra industri rumahan (home industry). Desain penelitian ini ialah cross-sectional study. Contoh dalam penelitian ini adalah remaja, yang memiliki ibu bekerja, dari empat SMP terpilih di lokasi penelitian. Jumlah responden dalam penelitian ini adalah 80 ibu dan anak remajanya (160 responden) yang terpilih melalui secara purposive. Pada model regresi pertama, ditemukan bahwa temperamen remaja yaitu dimensi effortful control (pengendalian diri) berpengaruh signifikan positif terhadap interkasi ibu-remaja. Sementara itu, temperamen remaja yaitu dimensi negative affectivity (reaktivitas rendah) berpengaruh signifikan negatif terhadap interaksi iburemaja. Selanjutnya, pada model regresi kedua ditemukan interkasi ibu remaja (versi remaja) berpengaruh signifikan positif terhadap kecerdasan emosional remaja.
\end{abstract}

Kata kunci: ibu bekerja, interaksi ibu-remaja, kecerdasan emosi, temperamen remaja

\section{Temperament, Mother-Adolescent Interaction, and Adolescent's Emotional Intelligence on Working Mother Families in Rural Area}

\begin{abstract}
This study aimed to analyze the influence of adolescent characteristics and family characteristics on motheradolescent interactions and analyzing the influence of adolescent characteristics, family characteristics, and mother-adolescent interactions on adolescent emotional intelligence in adolescent with working mother. This research was conducted in Ciampea, Bogor Regency that chosen purposively with consideration as rural area and location of home industry. The design of this research is cross-sectional study. Samples are adolescents with working mothers, from four selected junior high schools. Total samples were 160, consist of 80 mothers and adolescents that selected purposively. In the first regression model, it was found that effortful control (dimension of adolescent temperament) has a significant positive effect on mother-adolescent interaction. Meanwhile, negative affectivity (dimension of adolescent temperament) has a significant negative effect on mother-adolescent interaction. Furthermore, in the second regression model found that mother-adolescent interaction (adolescent version) has a significant positive effect on adolescent emotional intelligence.
\end{abstract}

Keywords: adolescent's temperament, emotional intelligence, mother-adolescent interaction, working mother

\section{PENDAHULUAN}

Fakta menyebutkan bahwa terdapat peningkatan tingkat partisipasi kerja perempuan (lebih dari 50,0\%) dan diperkirakan meningkat karena akses perempuan lebih besar terhadap pendidikan dan pelatihan (ILO, 2014). International Labour Organization (2014) menyatakan transisi perempuan dari pekerja domestik menjadi pekerja eksternal merupakan tantangan, seperti tuntutan jam kerja perempuan yang tidak fleksibel.
Fenomena ibu bekerja ini memberikan dampak, tidak hanya bagi ibu sebagai individu, tetapi juga keluarga. Ibu, sebagai orang yang memiliki peranan penting dalam pengasuhan, akan menghasilkan efek pengasuhan yang berbeda ketika ibu memiliki status bekerja (Puspitawati \& Setioningsih, 2011). Penelitian lainnya (Bianchi \& Milkie, 2010) menyebutkan bahwa ada kemungkinan status bekerja pada ibu akan memberikan efek negatif kepada anak remajanya, terutama pada keluarga dengan penghasilan rendah. 
Usia remaja, sekitar 12 hingga 16 tahun, merupakan kelompok usia remaja awal (Santrock, 2014). Santrock (2014) menyebutkan bahwa memasuki usia tersebut, remaja seringkali merasakan perubahan hidup yang semakin cepat dan kompleks, yang mudah menimbulkan stres, kecemasan, depresi, dan berbagai emosi negatif yang tidak bisa dihindari secara penuh oleh individu. Emosi merupakan respon yang diberikan oleh remaja terhadap suatu stimulus dari dalam dirinya dan dari luar dirinya sehingga anak dapat beradaptasi dan terhindar dari perilaku perilaku agresif (Hughes et al., 1998 dalam Ulutas \& Omeglu, 2008). Hal ini sangatlah diperlukan agar remaja dapat diterima dalam masyarakat. Ekspresi marah, sedih, dan takut merupakan emosi dasar seseorang yang diidentikkan dengan emosi negatif (Goleman, 2015). Oleh karena itu, orang dewasa yang diharapkan untuk dapat melakukan diskusi bersama remaja tersebut adalah orang tua, sebagai pihak yang memiliki intensitas kebersamaan paling besar dan pihak pertama yang memberikan dasar-dasar nilai bagi anak (Gentry \& Campbell, 2002). Respon orang tua, terutama ibu, terhadap perilaku anak dalam kehidupan sehari-hari sangat memengaruhi pembelajaran emosi remaja, terutama ketika mereka mengalami stres, kesedihan, kemarahan, atau perasaan bersalah (Santrock, 2007).

Temperamen merupakan salah satu karakteristik anak yang dapat memengaruhi interaksi antara anak dan orang tua, khususnya ibu sebagai pengasuh utama (Lestari, 2012). Santrock (2007) menyatakan bahwa temperamen adalah gaya perilaku dan karakteristik respons dari seseorang. Penelitian-penelitian sebelumnya (Stoltzfus \& Karraker, 2009) mengungkapkan bahwa kesesuaian antara temperamen anak dengan perilaku orang tua dapat menghasilkan perkembangan anak yang optimal. Lerner et al. (1985) telah menyebutkan suatu model, dimana temperamen anak berpengaruh terhadap interaksi ibu-anak dan secara tidak langsung berpengaruh terhadap perkembangan optimal yang dialami oleh anak. Temperamen merupakan karakteristik individu yang menentukan afektif seseorang serta memerankan peran dalam interaksi dan fungsi sosial (Calkins, 2012). Temperamen telah dimiliki seseorang sejak lahir. Namun tingginya interaksi dengan lingkungan dapat memengaruhi temperamen atau temperamen berkembang sebagai hasil elaborasi dengan pengalaman masa kanak-kanak hingga remaja dan menjadi suatu kepribadian (Caspi \&
Shiner, 2006 dalam Santrock, 2014). Penelitian sebelumnya juga menyatakan bahwa interaksi yang berkualitas terdiri dari atensi dan penerimaan orang tua yang dirasakan oleh remaja (Lerner et al., 1998).

Interaksi ibu-anak yang baik dapat membantu remaja untuk memiliki kecerdasan emosi yang baik (Santrock, 2007). Tujuan dari interaksi yang dilakukan oleh ibu kepada anak remajanya adalah membangun kesesuaian antara karakteristik dan kemampuan remaja dengan tuntutan dan ekspektasi dari lingkungan (Santrock, 2014). Hasil penelitian sebelumnya menyebutkan remaja yang merasakan penerimaan orang tuanya melalui interaksi orang tua-remaja berhubungan dengan kemampuan remaja untuk mengetahui dan mengelola emosi, serta menyelesaikan permasalahan yang dihadapinya (Kim et al., 2003; Rueter \& Conger, 1995).

Beberapa penelitian menemukan bahwa kecerdasan emosi erat kaitannya dengan karakteristik pengasuh atau ibu. Hasil penelitian Puspitawati dan Setioningsih (2011) menemukan bahwa karakteristik keluarga, yaitu pendapatan ibu, dapat meningkatkan kecerdasan emosi anak. Hurlock (1999) menyebutkan bahwa ibu yang lebih berumur cenderung menerima perannya sepenuh hati sebagai ibu sehingga berpengaruh terhadap kuantitas dan kualitas pengasuhan anak, yang akhirnya akan berpengaruh juga terhadap kecerdasan emosi anak. Hasil penelitian lainnya yang dilakukan oleh Febriana (2001) menemukan bahwa riwayat pendidikan ibu juga berpengaruh signifikan terhadap kecerdasan emosi anak. Walaupun penelitian mengenai interaksi ibu-remaja dan kecerdasan emosi remaja sudah banyak dilakukan, belum banyak penelitian yang meneliti kedua variabel tersebut dan dihubungkan dengan temperamen remaja. Begitu pula dengan penelitian mengenai keluarga remaja di perdesaan. Keluarga perdesaan, yang diidentikkan dengan permasalahan sosial ekonomi, seringkali mengalami permasalahan dalam menerapkan pengasuhan yang baik (Papalia, Olds, \& Fieldman, 2009). Berdasarkan pemaparan terebut, penelitian ini bertujuan menganalisis pengaruh karakteristik remaja dan karakteristik keluarga terhadap interaksi ibu-remaja pada keluarga remaja dengan ibu bekerja di perdesaan. Penelitian ini juga bertujuan menganailsis pengaruh karakteristik remaja, karakteristik keluarga, dan interaksi ibu-remaja terhadap kecerdasan emosi remaja pada keluarga remaja dengan ibu bekerja di perdesaan. 


\section{METODE}

Penelitian ini menggunakan desain crosssectional study. Penelitian dilaksanakan di Kabupaten Bogor, Jawa Barat. Lokasi dipilih secara purposive karena Kabupaten Bogor merupakan lokasi dengan partisipasi ibu bekerja tertinggi di Jawa Barat berdasarkan laporan kinerja pemerintah (LAKIP) Kabupaten Bogor 2014 (Prolap Inspektorat Kabupaten Bogor, 2015). Kecamatan Ciampea dipilih secara purposive karena Kecamatan Ciampea merupakan wilayah dengan arah pengembangan industri non-farm dengan banyaknya sentra industri rumahan (home industry) sehingga lebih besar peluang untuk mendapatkan keluarga dengan anak remaja yang memiliki ibu bekerja (Prolap Inspektorat Kabupaten Bogor, 2015).

Populasi dalam penelitian ini adalah ibu bekerja dengan anak remaja yang tinggal di wilayah Kecamatan Ciampea, Kabupaten Bogor. Penarikan contoh dilakukan secara purposive, yaitu ibu bekerja dan anak remaja yang bersekolah di sekolah terpilih. Sekolah yang terpilih adalah SMP PGRI Ciampea, SMP Plus Darrul Solihin, SMP Madani, dan SMP Hanura. Sekolah-sekolah tersebut dipilih karena berada di daerah dengan banyak industri rumahan yaitu Desa Bojong Rangkas, Desa Cihideung llir, Desa Cihideung Udik, dan Desa Cinangka (Prolap Inspektorat Kabupaten Bogor, 2015). Berdasarkan data yang dikumpulkan dari empat sekolah tersebut, jumlah anak remaja dengan ibu bekerja adalah 115 orang anak remaja. Jumlah responden yang berhasil diolah datanya adalah 80 responden anak remaja dan ibunya (160 responden) dengan pertimbangan memilih keluarga dengan anak remaja yang tinggal bersama ibunya pada saat pengambilan data berlangsung.

Data yang digunakan dalam penelitian ini adalah data primer dan data sekunder. Data primer diperoleh melalui self-administered, untuk remaja, dan wawancara, untuk ibu, dengan bantuan kuesioner. Data primer meliputi karakteristik remaja (usia remaja, jenis kelamin remaja, temperamen remaja), karakteristik orang tua (lama pendidikan ibu, jenis pekerjaan ibu, pendapatan ibu, lama kerja ibu), interaksi ibu-remaja, dan kecerdasan emosi remaja.

Data mengenai karakteristik temperamen diperoleh dengan menggunakan instrumen yang diadopsi dari EATQ-R (Early Adolescent Temperament Questionnaire-Revised) yang dibuat oleh Putnam, Ellis, dan Rothbart (1999). Pengukuran EATQ-R digunakan untuk mengetahui temperamen remaja selanjutnya digolongkan dalam empat dimensi berdasarkan reaktivitas dan pengaturan diri yaitu surgency, negative affectivity, effortful control, dan affiliativeness. Surgency adalah temperamen dengan ciri khas remaja dengan keceriaan, spontanitas, cepat tanggap, dan mudah bergaul. Efforful control adalah temperamen dengan ciri khas remaja dengan kemampuan pengendalian diri. Affiliativeness adalah temperamen dengan ciri khas remaja mudah mempertahankan hubungan. Negative affectivity adalah temperamen dengan ciri khas kepribadian yang sulit. Berdasarkan instrumen tersebut, temperamen terdiri dari 12 subdimensi yaitu kesenangan, takut, malu, frustasi, perasaan depresi, agresi, perhatian atau atensi, kontrol diri untuk tidak melakukan sesuatu kegiatan (inhibitory control), kontrol diri untuk melakukan sesuatu kegiatan (activation control), afiliasi, sensitivitas persepsi (perceptual sensitivity), dan sensitivitas akan sesuatu yang menyenangkan (pleasure sensitivity). Pernyataan asli dalam instrumen ini berisikan 65 pernyataan yang menyangkut empat dimensi temperamen tersebut. Lima poin skala Likert digunakan untuk mengukur persepsi remaja mengenai pernyataan yang merujuk kepada temperamen remaja. Namun, hasil uji reliabilitas menunjukkan angka yang kurang baik $(\alpha<0,700)$. Oleh karena itu, penelitian ini hanya menggunakan 48 pernyataan yang menyangkut keempat dimensi temperamen remaja. Beberapa pernyataan yang tidak dipakai adalah 2, 5, 6, 7, 8, 9, 10, 13, 15, 18, $19,20,26,34,35,38$, dan 57. Reliabilitas dari kuesioner temperamen remaja ini adalah 0,720 .

Instrumen interaksi ibu-remaja menggunakan instrumen PACHIQ-R (The Parent-Child Interaction Questionnaire-Revised) yang dibuat oleh Lange et al. (2002). PACHIQ-R terbagi menjadi dua pengukuran yaitu pengukuran interaksi versi orang tua dan versi remaja. Pengukuran versi orang tua terdiri dari 21 pernyataan sedangkan versi anak remaja terdiri dari 25 pernyataan dengan lima poin skala Likert. Dimensi interaksi ibu-remaja adalah resolusi konflik dan penerimaan. Chronbach's Alpha instrumen interaksi iburemaja versi remaja sebesar 0,755 , sedangkan versi ibu sebesar 0,716.

Data mengenai kecerdasan emosi remaja didapatkan dengan menggunakan kuesioner kecerdasan emosi (Rachmawati, 2015) yang 
dikembangkan dari kecerdasan emosi Goleman (1995). Instrumen kecerdasan remaja terdiri dari 30 pernyataan yang terbagi menjadi 9 dimensi kesadaran diri, 6 dimensi pengaturan diri, 6 dimensi motivasi, 4 dimensi empati, dan 5 dimensi keterampilan sosial. Instrumen ini fokus kepada kemampuan remaja dalam mengelola emosi, khususnya emosi marah, sedih, dan takut. Pengukuran menggunakan skala Likert yang terdiri dari hampir tidak pernah diberi skor 1 , jarang diberi skor 2, sering diberi skor 3 , dan selalu diberi skor 4. Hasil uji reliabilitas kuesioner ini menunjukkan angka yang kurang baik $(\alpha<0,700)$, maka penelitian ini hanya menggunakan 22 pernyataan. Beberapa pernyataan yang tidak dipakai adalah 9, 10, 11, 15, 18, 21, dan 22. Reliabilitas dari kuesioner kecerdasan emosi remaja ini adalah 0,707 .

Analisis data dilakukan secara deskriptif dan inferensia. Analisis deskriptif (jumlah, persentase, nilai rataan, standar deviasi, nilai minimum dan maksimum) digunakan untuk menggambarkan karakteristik remaja dan keluarga, temperamen remaja, interaksi iburemaja, dan kecerdasan emosi remaja. Analisis inferensia meliputi analisis regresi untuk mengetahui pengaruh karakteristik remaja, karakteristik keluarga, temperamen, dan interaksi ibu remaja terhadap kecerdasan emosi remaja. Sebelum dilakukan analisis, data mentah diolah dengan mengubahnya ke dalam bentuk indeks $(0,0-100,0)$.

\section{HASIL}

\section{Karakteristik Remaja}

Karakteristik remaja dibagi menjadi tiga yaitu jenis kelamin, usia, dan temperamen remaja. Remaja perempuan pada penelitian ini berjumlah 41 orang atau lebih dari separuh dari total responden penelitian. Usia remaja berkisar antara 12 hingga 16 tahun yang duduk di bangku sekolah menengah pertama (SMP). Rata-rata usia remaja adalah 13,84 tahun. Usia remaja terbanyak adalah 14 tahun $(38,8 \%)$ sedangkan paling sedikit ialah usia 16 tahun $(1,2 \%)$.

Tabel 1 Nilai minimum, maksimum, rata-rata, dan standar deviasi indeks temperamen

\begin{tabular}{lcc}
\hline \multicolumn{1}{c}{ Dimensi } & Min-Maks & Rata-rata \pm SD \\
\hline Surgency & $11,0-84,0$ & $44,9 \pm 15,7$ \\
Effortful control & $30,0-90,0$ & $63,0 \pm 13,7$ \\
Affilliativeness & $33,0-92,0$ & $64,5 \pm 13,6$ \\
Negative affectivity & $20,0-91,0$ & $54,2 \pm 14,6$ \\
\hline
\end{tabular}

Temperamen telah dimiliki seseorang sejak lahir. Hasil penelitian pada Tabel 1 menunjukkan rata-rata indeks capaian pada dimensi temperamen affiliativeness merupakan faktor temperamen yang paling tinggi dimiliki oleh remaja. Selanjutnya, dimensi effortful control merupakan temperamen dengan nilai rata-rata capaian yang juga tinggi, yaitu 63,0.

Hasil penelitian menunjukkan rata-rata indeks capaian pada dimensi temperamen affiliativeness $(38,0 \%)$ merupakan dimensi temperamen yang mendominasi temperamen remaja. Hal ini menunjukkan bahwa lebih dari separuh remaja memiliki dominasi temperamen affiliativeness, yaitu karakteristik kepribadian yang memperlihatkan kemampuan individu untuk memiliki kedekatan, kehangatan, kooperatif, dan simpatik kepada orang lain. Selanjutnya, effortful control merupakan dimensi temperamen yang juga banyak dimiliki oleh remaja. Selain itu, hanya 10,0 persen remaja yang memiliki dominasi temperamen surgency. Hal ini menunjukkan bahwa hanya sedikit remaja yang memiliki karakteristik kepribadian dengan ciri-ciri individu yang penuh keceriaan, spontanitas, cepat tanggap (responsive), dan mudah bergaul.

\section{Karakteristik Keluarga}

Usia ibu dapat dikategorikan menjadi tiga berdasarkan Papalia, Olds, dan Feldman (2009) yaitu dewasa muda (20-40 tahun), dewasa madya (41-65 tahun), dan dewasa lanjut (>65 tahun). Kategori usia ibu paling banyak $(55,0 \%)$ berada pada kategori dewasa madya dan tidak ada satu pun ibu yang berusia diatas 65 tahun. Rata-rata usia ibu adalah 42,56 tahun. Hasil penelitian ini menunjukkan bahwa lebih dari separuh $(61,2 \%)$ ibu telah menempuh pendidikan tamat sekolah dasar. Rata-rata lama pendidikan ibu adalah 7,02 tahun. Sebagian besar pekerjaan ibu berada pada sektor informal, seperti berwirausaha dengan skala kecil atau pembantu rumah tangga. Pendapatan yang diterima ibu pun beragam dari rentang Rp175.000,00 hingga Rp10.000.000,00 per bulan. Selain itu, lama kerja ibu pun beragam yaitu 2 jam/hari hingga 19 jam/hari. Rata-rata lama kerja ibu adalah 9,37 jam/hari.

\section{Interaksi lbu-Remaja}

Ibu merupakan pembentuk jalinan hubungan yang pertama dan terutama dalam kehidupan seorang anak. Penelitian ini melihat interaksi 
ibu-remaja dari persepsi ibu dan remaja, berdasarkan dimensi resolusi konflik (perilaku) dan penerimaan. Dimensi resolusi konflik menunjukkan bagaimana perilaku ibu terhadap remajanya yang diungkapkan dalam interaksi ibu-remaja sehari-hari. Dimensi penerimaan menunjukkan bagaimana perasaan yang dirasakan oleh ibu atau remaja akan kualitas interaksi ibu-remaja yang terjadi sehari-hari. Uji korelasi dilakukan untuk mengetahui apakah terdapat hubungan antara persepsi interaksi ibu-remaja versi ibu dan versi remaja. Hasil uji menunjukkan bahwa tidak ada hubungan antara keduanya. Hal ini berarti bahwa persepsi mengenai kualitas interaksi iburemaja yang diungkapkan oleh ibu berbeda dengan persepsi kualitas interaksi ibu-remaja yang diungkapkan oleh remaja. Apabila ibu merasa bahwa kualitas interaksi antara ibu dan anak remajanya adalah baik, hal ini tidak berarti bahwa remaja merasakan hal yang sama.

Nilai rata-rata interaksi ibu-remaja yang dirasakan oleh ibu lebih tinggi dibandingkan dengan versi remaja (Tabel 2). Selain itu, hasil penelitian ini juga memperlihatkan bahwa nilai rata-rata penerimaan ibu terhadap anak remajanya lebih tinggi dibandingkan nilai ratarata resolusi konflik yang ditawarkan ibu kepada anak remajanya. Hal ini berbeda pada interaksi versi remaja. Nilai rata-rata resolusi konflik yang dialami oleh remaja lebih tinggi dibandingkan dengan penerimaan yang diterima oleh remaja.

\section{Kecerdasan Emosi Remaja}

Tabel 3 menunjukkan hasil analisis deskriptif kecerdasan emosi dan dimensinya, yang teridir dari kesadaran diri, pengaturan diri, motivasi, empati, dan keterampilan sosial. Hampir separuh remaja mengetahui ketika dirinya sedih $(48,8 \%)$, marah $(40,0 \%)$, dan takut $(41,2 \%)$. Ketika remaja merasakan emosi sedih, satu dari delapan remaja tidak mengetahui alasan kesedihannya dan mengungkapkan kesedihan tersebut dengan menangis dan mengurung diri di kamar. Ketika remaja merasakan emosi marah, remaja $(38,8 \%)$ hampir selalu mengetahui alasan kemarahannya tersebut dan mengungkapkan kemarahannya tanpa merusak barang dan tidak terdorong untuk melampiaskannya kepada benda atau orang lain. Satu dari delapan remaja juga tidak mengetahui alasan ketakutan yang dirasakan oleh dirinya. Remaja $(31,2 \%)$ mengungkapkan ketakutannya dengan cara menyakini diri sendiri bahwa dirinya dapat mengatasi ketakutan tersebut.
Tabel 2 Nilai minimum, maksimum, rata-rata, dan standar deviasi indeks interaksi ibu-remaja

\begin{tabular}{lcccc}
\hline \multirow{2}{*}{ Dimensi } & \multicolumn{2}{c}{ Versi lbu } & \multicolumn{2}{c}{ Versi Remaja } \\
\cline { 2 - 5 } & $\begin{array}{c}\text { Min- } \\
\text { Maks }\end{array}$ & $\begin{array}{c}\text { Rata- } \\
\text { rata } \\
\text { SD }\end{array}$ & $\begin{array}{c}\text { Min- } \\
\text { Maks }\end{array}$ & $\begin{array}{c}\text { Rata- } \\
\text { rata } \pm \\
\text { SD }\end{array}$ \\
\hline Interaksi & $51,0-$ & $80,8 \pm$ & $38,0-$ & $68,0 \pm$ \\
ibu-Remaja & 100,0 & 10,9 & 94,0 & 11,4 \\
Resolusi & $44,0-$ & $79,2 \pm$ & $37,0-$ & $69,8 \pm$ \\
konflik & 100,0 & 12,2 & 94,0 & 11,9 \\
Penerimaan & $36,0-$ & $83,0 \pm$ & $28,0-$ & $64,1 \pm$ \\
& 100,0 & 13,2 & 94,0 & 14,8 \\
\hline
\end{tabular}

Tabel 3 memperlihatkan bahwa walaupun setiap dimensi kecerdasan emosi merupakan suatu tahapan, tidak ada remaja yang berhasil mendapatkan nilai maksimal atau 100,0 pada seluruh dimensinya. Rata-rata indeks capaian terbaik terdapat pada dimensi kesadaran diri yaitu sebesar 55,7. Sementara itu, rata-rata indeks capaian terendah terdapat pada dimensi motivasi yaitu sebesar 32,5. Rata-rata capaian kecerdasan emosi remaja adalah 70,0 . Hal ini menunjukkan bahwa secara keseluruhan, remaja memiliki kecerdasan emosi yang baik tetapi memiliki kemampuan per dimensi yang rendah.

\section{Pengaruh Karakteristik dan Temperamen Remaja, serta Karakteristik Keluarga terhadap Interaksi lbu-Remaja}

Penelitian ini melakukan uji pengaruh antara karakteristik dan temperamen remaja serta karakteristik keluarga terhadap interaksi iburemaja (versi remaja). Hasil tersebut diperlihatkan pada Tabel 4. Hasil memperlihatkan bahwa remaja dengan dominansi temperamen Effortful control berpengaruh secara signifikan $(B=0,322)$ terhadap kualitas interaksi ibu-remaja yang dirasakan oleh remaja. Hal ini berarti bahwa setiap bertambahnya satu satuan kemampuan mempertahankan sistem pengendalian diri (temperamen effortful control) yang dimiliki oleh remaja maka akan meningkatkan kualitas interaksi ibu-remaja yang dirasakan remaja.

Tabel 3 Nilai minimum, maksimum, rata-rata, dan standar deviasi indeks kecerdasan emosi remaja

\begin{tabular}{lcc}
\hline Dimensi & Min-Maks & Rata-rata \pm SD \\
\hline Kecerdasan emosi & $44,0-98,0$ & $70,0 \pm 12,6$ \\
Kesadaran diri & $21,0-86,0$ & $55,7 \pm 15,8$ \\
Pengaturan diri & $0,0-43,0$ & $35,6 \pm 9,1$ \\
Motivasi & $10,0-60,0$ & $32,5 \pm 13,5$ \\
Empati & $0,0-69,0$ & $43,3 \pm 15,1$ \\
Keterampilan sosial & $19,0-75,0$ & $49,5 \pm 13,5$ \\
\hline
\end{tabular}


Tabel 4 Hasil analisis regresi linier pada karakteristik remaja, serta karakteristik keluarga terhadap interaksi ibu-remaja (versi remaja)

\begin{tabular}{lrrrr}
\hline Variabel Bebas & B & \multicolumn{1}{c}{ Std. Error } & \multicolumn{1}{c}{ Sign. } \\
\hline Konstanta & 42,815 & 21,840 & & 0,054 \\
Karakteristik remaja & & & & \\
Usia remaja (tahun) & 2,227 & 1,259 & 0,185 & 0,081 \\
Jenis kelamin (0=laki-laki; 1=perempuan) & $-3,527$ & 2,481 & $-0,156$ & 0,160 \\
Temperamen remaja & & & & \\
Surgency (indeks) & 0,061 & 0,077 & 0,084 & 0,435 \\
Effortful control (indeks) & 0,322 & 0,091 & 0,388 & $\mathbf{0 , 0 0 1}$ \\
Affilliativeness (indeks) & 0,055 & 0,101 & 0,066 & 0,585 \\
Negative affectivity (indeks) & $-0,256$ & 0,087 & $-0,330$ & $\mathbf{0 , 0 0 4}$ \\
Karakteristik keluarga & & & & \\
Usia ibu (tahun) & $-0,264$ & 0,190 & $-0,155$ & 0,169 \\
Lama pendidikan ibu (tahun) & $-0,223$ & 0,471 & $-0,053$ & 0,638 \\
Pendapatan ibu (rupiah/bulan) & $1,315 \mathrm{E}-6$ & 0,000 & 0,194 & 0,097 \\
Lama kerja ibu (jam/hari) & $-0,288$ & 0,313 & $-0,105$ & 0,361 \\
\hline $\mathrm{R}^{2}$ & & 0,343 & & \\
Adjusted R Square & & 0,248 & & \\
F & & 3,604 & & \\
Sig. & & 0,001 & & \\
Keterangan: ${ }^{*}=$ signifikan pada $p<0,05 ;{ }^{* *}=$ signifikan pada $p<0,01$ & & & &
\end{tabular}

Hasil analisis juga menemukan bahwa dominansi temperamen negative affectivity dapat memengaruhi kualitas interaksi iburemaja yang dirasakan oleh remaja secara negatif signifikan $(B=-0,256)$. Hal ini berarti bahwa setiap bertambahnya satu satuan temperamen negative affectivity yang dirasakan oleh remaja maka akan menurunkan kualitas interaksi ibu-remaja yang dirasakan oleh remaja.

Tabel 5 Hasil analisis regresi linier pada variabel bebas terhadap kecerdasan emosi remaja

\begin{tabular}{|c|c|c|c|c|}
\hline Variabel Bebas & $\mathrm{B}$ & Std. Error & $\beta$ & Sign. \\
\hline Konstanta & $-0,354$ & 25,015 & & 0,989 \\
\hline \multicolumn{5}{|l|}{ Karakteristik remaja } \\
\hline Usia remaja (tahun) & 1,363 & 1,422 & 0,103 & 0,341 \\
\hline $\begin{array}{l}\text { Jenis kelamin }(0=\text { laki-laki; } \\
1=\text { perempuan })\end{array}$ & 3,467 & 2,764 & 0,139 & 0,214 \\
\hline \multicolumn{5}{|l|}{ Temperamen remaja } \\
\hline Surgency (indeks) & $-0,159$ & 0,085 & $-0,199$ & 0,067 \\
\hline Effortful control (indeks) & 0,122 & 0,108 & 0,133 & 0,263 \\
\hline Affilliativeness (indeks) & 0,069 & 0,110 & 0,075 & 0,532 \\
\hline Negative affectivity (indeks) & 0,101 & 0,101 & 0,118132 & 0,317 \\
\hline \multicolumn{5}{|l|}{ Karakteristik keluarga } \\
\hline Usia ibu (tahun) & $-0,249$ & 0,212 & $-0,132$ & 0,245 \\
\hline Lama pendidikan ibu (tahun) & 0,417 & 0,514 & 0,090 & 0,420 \\
\hline Pendapatan ibu (rupiah/bulan) & $-2,157 \mathrm{E}-7$ & 0,000 & $-0,029$ & 0,806 \\
\hline Lama kerja ibu (jam/hari) & 0,044 & 0,344 & 0,014 & 0,899 \\
\hline $\begin{array}{l}\text { Interaksi ibu-remaja versi ibu } \\
\text { (indeks) }\end{array}$ & 0,141 & 0,120 & 1,171 & 0,246 \\
\hline $\begin{array}{l}\text { Interaksi ibu-remaja versi } \\
\text { remaja (indeks) }\end{array}$ & 0,471 & 0,131 & 3,584 & $0,001^{\star \star}$ \\
\hline $\mathrm{F}$ & & 3,377 & & \\
\hline Sig. & & 0,001 & & \\
\hline $\mathrm{R}^{2}$ & & 0,377 & & \\
\hline Adjusted R Square & & 0,265 & & \\
\hline
\end{tabular}


Hasil uji regresi linier pada penelitian ini menemukan bahwa variabel yang paling berpengaruh secara positif signifikan terhadap kecerdasan emosi remaja ialah kualitas interaksi ibu-remaja yang dirasakan oleh remaja, yang ditunjukkan dengan nilai $B$ sebesar 0,471 . Hal ini berarti bahwa setiap bertambahnya satu satuan kualitas interaksi ibu-remaja yang dirasakan oleh remaja maka akan meningkatkan kecerdasan emosi pada remaja sebesar 0,471 poin. Nilai adjusted $\mathrm{R}$ square dari model regresi yaitu 0,265 yang berarti, sebesar 26,5 persen kecerdasan emosi remaja dipengaruhi oleh variabel-veriabel dalam penelitian, sedangkan sisanya dipengaruhi oleh variabel bebas lainnya di luar peneltian.

Hasil pada Tabel 4 dan 5 menunjukkan bahwa temperamen lebih memengaruhi kecerdasan emosi remaja melalui interaksi ibu-remaja, mengingat temperamen lebih menunjukkan pengaruh terhadap interaksi ibu-remaja dibandingkan dengan kecerdasan emosi remaja. Sejalan dengan hasil tersebut, Hasil regresi terhadap interaksi ibu-remaja versi remaja (Tabel 4) menemukan bahwa beberapa dominansi temperamen remaja dapat memengaruhi kualitas interaksi ibu-remaja yang dirasakan oleh remaja.

\section{PEMBAHASAN}

Usia remaja pada penelitian ini berkisar antara 12 hingga 16 tahun yang duduk di bangku sekolah menengah pertama (SMP). Usia remaja terbanyak adalah 14 tahun $(38,8 \%)$ sedangkan paling sedikit ialah usia 16 tahun $(1,2 \%)$. Berdasarkan Hurlock (1950), responden penelitian ini berada dalam usia remaja awal (early adolescence), yaitu di antara usia 11-18 tahun. Secara khusus, remaja pada tahapan ini mengalami pertumbuhan fisik dan perubahan organ seksual yang cepat sehingga memengaruhi perkembangan biologis, kognitif, dan sosioemosional anak. Perkembangan yang dialami oleh remaja dipengaruhi oleh faktor bawaan, faktor lingkungan, dan pengalaman masa kanak-kanak (Santrock, 2014). Berdasarkan teori psikososial Erikson, remaja awal memiliki tugas perkembangan utama yaitu menemukan identitas dirinya (identity versus role confusion). Kemampuan berhubungan dengan orang lain, khususnya ibu, dapat membantu remaja untuk menemukan identitas dirinya. Melalui kesempatan itu pula, remaja dapat belajar untuk memahami dan mengontrol emosi dari ibu. Sesuai dengan teori ekologi
Bronfenbrenner, perkembangan seseorang dimulai dari lingkungan mikro, yaitu keluarga.

Goleman (2015) mengukur kemampuan berhubungan dengan orang lain melalui tahapan kecerdasan emosional, yaitu kesadaran diri, pengaturan diri, motivasi, empati, dan keterampilan sosial. Penelitian ini menemukan bahwa tidak ada remaja yang berhasil mendapatkan nilai sempurna pada kecerdasan emosi. Hal ini menunjukkan bahwa anak memiliki kecerdasan emosi yang baik secara keseluruhan tetapi per dimensi masih rendah. Sementara itu, Sari (2011) menemukan bahwa kematangan emosional pada remaja laki-laki (usia 16-18 tahun) tidak ada yang terkategori rendah. Hal ini menunjukkan pada usia 16 tahun ke atas, individu diduga telah menunjukkan kematangan emosi.

Pada penelitian ini capaian kecerdasan emosi yang dimiliki oleh remaja dengan ibu bekerja belum tinggi. Capaian ini lebih rendah apabila dibandingkan dengan kecerdasan emosi remaja pada keluarga perdesaan yang telah dilakukan sebelumnya (Rachmawati, 2015). Penelitian ini menemukan bahwa faktor yang memengaruhi rendahnya capaian kecerdasan emosi remaja adalah kualitas interaksi iburemaja yang dirasakan oleh remaja. Sejalan dengan penelitian sebelumnya, Santrock (2007) menyatakan bahwa kecerdasan emosi yang baik dipengaruhi oleh interaksi ibu-anak yang baik. Interaksi ibu-remaja dalam penelitian ini terdiri dari dua struktur yaitu resolusi konflik dan penerimaan, yang menggambarkan perilaku dan perasaan interpersonal antara ibu dan anak. Hasil penelitian ini menemukan bahwa nilai rata-rata interaksi ibu-remaja yang dirasakan oleh ibu lebih tinggi dibandingkan dengan versi remaja, baik secara umum maupun per dimensinya.

Faktor lain yang dapat memengaruhi rendahnya kecerdasan emosi remaja dalam penelitian ini adalah temperamen remaja. Temperamen telah ada dari bayi dan bertahan hingga masa dewasa (Thomas \& Chess, 1977 dalam Hooper \& Umansky, 2009). Hasil penelitian menemukan indikasi bahwa temperamen memengaruhi kecerdasan emosi remaja, secara tidak langsung, melalui kualitas interaksi ibu-remaja yang dirasakan oleh remaja. Lebih spesifik, hasil penelitian menunjukkan bahwa remaja dengan kecenderungan memiliki reaktivitas yang rendah (negative affectivity) memiliki pengaruh secara negatif signifikan dengan kualitas interaksi ibu-remaja yang dirasakan oleh 
remaja. Temperamen memengaruhi interaksi ibu-remaja karena temperamen membentuk ciri khas yang dimiliki oleh remaja dalam merespon lingkungannya (Gallagher, 2002). Hasil ini sejalan dengan proses model Lerner (1985) yaitu temperamen anak berpengaruh secara langsung terhadap interaksi ibu-anak dan berpengaruh secara tidak langsung terhadap perkembangan anak. Penelitian sebelumnya yang dilakukan oleh Stoltzfus dan Karraker (2009) mengungkapkan bahwa kesesuaian antara temperamen anak dengan perilaku orang tua dapat menghasilkan perkembangan anak yang optimal.

Penelitian ini menemukan bahwa rata-rata indeks capaian affiliativeness merupakan faktor temperamen yang paling tinggi dimiliki oleh remaja. Affiliativeness merupakan karakteristik kepribadian yang memperlihatkan kemampuan individu untuk memiliki kedekatan, kehangatan, kooperatif, dan simpatik kepada orang lain. Sementara itu, rata-rata indeks capaian surgency merupakan faktor temperamen yang paling kecil dimiliki oleh remaja. Surgency ialah karakteristik kepribadian dengan ciri-ciri individu yang penuh dengan keceriaan, spontanitas, cepat tanggap, dan mudah bergaul. Hal ini sejalan dengan hasil dominasi temperamen yang dimiliki oleh remaja. Penelitian ini menemukan bahwa 37,5 persen remaja memiliki dominasi temperamen affiliativeness. Sebaliknya, hanya 10,0 persen remaja yang memiliki dominasi temperamen surgency.

Efek pengasuhan orang tua terhadap remaja dapat terlihat melalui interaksi ibu-remaja (Lange et al., 2002). Melalui penelitian ini, kualitas interaksi ibu dan anak remajanya memiliki peranan penting dalam proses perkembangan anak, khususnya kecerdasan emosi. Melalui interaksi dengan ibu, remaja dapat belajar untuk menangani perasaan mereka sendiri sehingga menunjang pembelajaran dan perkembangan emosi anak. Goleman (2015) menyebutkan bahwa kecerdasan emosi terbentuk melalui pembelajaran emosi yang telah dimulai sejak awal kehidupan dan berlanjut sepanjang masa kehidupan manusia yang semuanya berawal dari lingkungan keluarga. Interaksi ibu-remaja juga merupakan jembatan untuk membentuk kesesuaian antara karakteristik dan temperamen, serta kemampuan remaja dengan tuntutan dan ekspekstasi dari lingkungan (Santrock, 2014). Penelitian Nasrudin (2013) menemukan bahwa terdapat hubungan signifikan positif antara fungsi afektif keluarga dengan kecerdasan emosi remaja.
Semakin baik fungsi afektif keluarga maka diduga kecerdasan emosional remaja akan semakin matang. Pengukuran fungsi afektif diukur melalui saling menghormati, saling asuh, hubungan yang akrab, serta keterpisahan dan keterpaduan. Lanjutnya, fungsi afektif kurang baik dapat disebabkan adanya konflik antara remaja dengan orang tua, terutama ibu.

Dalam konteks budaya, orangtua terutama ibu adalah pendidik utama anak. Interaksi dengan remaja sangat dipengaruhi oleh sistem kepercayaan dan norma masyarakat, salah satunya penerapan hukuman fisik yang diterima secara luas oleh masyarakat pada budaya tertentu (Sung, 2012). Situasi seperti ini berdampak pada kurang baiknya interaksi antara orang tua dengan remaja dan menjadi penghambat perkembangan remaja. Sung (2010) menemukan bahwa orang tua yang mengendalikan dan menghukum cenderung memiliki remaja dengan masalah emosional yang lebih besar. Anak-anak mungkin akan bersikap pasif-agresif sebagai respons dari kontrol orang tua yang berlebihan (Belsky, Rha \& Park, 2000). Lebih lanjut, Sung (2010) menyatakan perkembangan kecerdasan emosional secara optimal dipupuk di lingkungan rumah oleh orang tua yang berinisiatif memberikan umpan balik, menciptakan peluang, dan menjaga hubungan timbal balik yang baik dengan anak (Sung, 2010). Namun, orang tua seringkali tidak dapat menyesuaikan diri dengan kebutuhan anakanaknya, terutama saat orang tua berfokus pada permasalahan ekonomi, sosial, dan emosinya. Kondisi sosial di kota-kota besar di Asia dan Amerika menghadapi permasalahan yang sama, dengan dua orang tua bekerja, tingkat perceraian tinggi, dan tinggal di rumah orang tua tunggal. Kondisi sosial ini dapat menjadi penyebab masalah sosial lainnya. Selain itu, pada ibu bekerja, tanggung jawab fungsi pengasuhan ibu yang didelegasikan kepada orang lain akan berdampak pada lemahnya pengaruh orang tua dan dominannya pengaruh teman sebaya pada remaja (Sung, 2008; Luk-Fong, 2011; Leung \& Ching, 2011).

Penelitian ini menemukan adanya kesenjangan antara kualitas interaksi iburemaja yang dirasakan oleh ibu dan remaja. Berbeda dengan interaksi ibu-remaja yang dirasakan oleh remaja, persepsi kualitas interaksi ibu-remaja yang dirasakan oleh ibu tidak berpengaruh terhadap kecerdasan emosi remaja. Hal ini berarti bahwa apabila ibu merasa bahwa kualitas interaksinya dengan 
anak remajanya adalah baik, hal ini tidak berarti bahwa remaja merasakan hal yang sama.

Apabila dilihat lebih lanjut, beberapa pernyataan remaja berbeda dengan pernyataan ibu terkait kualitas interaksi yang terjadi di antara ibu dan remaja. Kurang dari setengah remaja dalam penelitian ini $(47,5 \%)$ merasa bahwa ibu menghargai apa yang mereka lakukan dalam hal membantu ibu. Sedangkan, ibu $(66,2 \%)$ merasa telah memperlihatkan apresiasi ketika anak melakukan sesuatu untuknya dan setengah ibu dari responden (50,0\%) sering memuji anak remajanya. Selain itu, hanya 41,2 persen remaja merasa ibu bangga dengan dirinya. Padahal, sebanyak 85,0 persen ibu merasa sangat bangga dengan anak remajanya. Bronfrenbrenner (1986) mengungkapkan bahwa status bekerja di luar rumah yang dimiliki oleh ibu akan berdampak negatif terhadap perkembangan anak. Oleh karenanya, ibu bekerja diharapkan tetap menjaga kualitas interaksi yang baik dengan anak remajanya sebagai alternatif dalam menyeimbangkan waktu yang terbatas akibat status bekerja pada ibu.

Penelitian ini masih memiliki beberapa keterbatasan. Pertama, teknik pengisian kuesioner, oleh remaja dalam penelitian, menggunakan self-administered. Selfadministered memungkinkan adanya bias terhadap pandangan remaja terhadap perilaku mereka sendiri dan perbedaan dalam mengartikan maksud dari pernyataan kuesioner. Kecerdasan emosi hanya berfokus kepada tiga emosi saja, yaitu marah, sedih, dan takut, sedangkan konsep yang digunakan adalah konsep umum. Oleh karena itu, penelitian selanjutnya dapat menggunakan instrumen lain untuk meneliti kecerdasan emosi remaja secara umum, dikaitkan dengan temperamen remaja dan interaksi ibu-remaja. Selain itu, ruang lingkup penelitian ini tidak menganalisis lebih lanjut mengenai interaksi apa yang paling tepat untuk setiap temperamen remaja.

\section{SIMPULAN DAN SARAN}

Usia remaja pada penelitian ini termasuk pada kategori usia remaja awal, yaitu berada pada rentang 12-16 tahun. Lebih dari separuh remaja memiliki dominansi temperamen affiliativeness yaitu karakteristik kepribadian yang penuh dengan kehangatan, kooperatif, dan simpatik terhadap orang lain. Lebih dari setengah ibu bekerja berada pada kategori usia dewasa madya dan masih berada di tingkat pendidikan SD sederajat. Jenis pekerjaan ibu yang paling banyak adalah sebagai pedagang atau wirausaha dengan rata-rata lama kerja 9,37 jam per hari. Ratarata pendapatan per bulan ibu sebesar Rp1.950.000,00.

Penelitian ini menemukan bahwa karakteristik dan temperamen remaja, serta karakteristik keluarga berhubungan dengan interaksi iburemaja, baik versi ibu maupun versi remaja. selain itu, karakteristik dan temperamen remaja, serta karakteristik keluarga juga berhubungan dengan kecerdasan emosi remaja. Interaksi ibu-remaja juga didapatkan berhubungan dengan kecerdasan emosi remaja. Penelitian ini menemukan kualitas interaksi ibu-remaja yang dirasakan oleh remaja berpengaruh sangat signifikan terhadap kecerdasan emosi remaja. Berbeda dengan versi remaja, persepsi kualitas interaksi ibu-remaja yang dirasakan oleh ibu sama sekali tidak berpengaruh terhadap kecerdasan emosi remaja. Hasil lainnya menunjukkan bahwa temperamen remaja berpengaruh secara tidak langsung terhadap kecerdasan emosi.

Hasil penelitian menemukan bahwa kualitas interaksi ibu-remaja yang dirasakan oleh ibu dan remajanya berbeda, yaitu ibu bekerja merasakan kualitas interaksi dengan anak remajanya lebih baik dibandingkan kualitas interaksi ibu-remaja yang dirasakan oleh remaja. Oleh karenanya, penelitian lebih lanjut diperlukan untuk menganalisis lebih lanjut mengenai interaksi ibu-remaja seperti apa yang paling tepat untuk menyesuaikan dengan temperamen yang dimiliki oleh remaja sehingga interaksi yang dilakukan oleh ibu bekerja, khususnya yang tinggal di perdesaan, dapat membantu dalam optimalisasi perkembangan remaja. Selain itu, sebaiknya ibu bekerja lebih banyak melakukan diskusi dengan anak remajanya dengan tujuan membangun persepsi yang sama antara ibu dan remaja mengenai hubungan yang terjalin antara ibu, sebagai orang tua, dengan remaja.

\section{DAFTAR PUSTAKA}

[ILO]. International Labour Organization. (2014). Indonesia: Tren Sosial dan Ketenagakerjaan. Diambil dari http://www.ilo.org/wcmsp5/groups/public/ ---asia/---ro-bangkok/---ilojakarta/documents/publication/wcms_32 9870.pdf [diunduh 20 Jan 2016]. 
Belsky, J., Rha, J., \& Park, S. (2000). Exploring reciprocal parent and child effects in the case of child inhibition in US and Korean samples. International Journal of Behavioral Development, 24(3), 338-347.

Bianchi, S. M., \& Milke, M. A. (2010). Work and family research in the first decade of the $21^{\text {st }}$ century. Journal of Marriage and Family, 72(3), 705-725. doi: 10.1111/j.1741-3737.2010.00726.x

Calkins, S. D. (2012). Temperament and its impact on child development: comments on rothbart, kagan, eisenberg, and schermerhorn and bates. Encyclopedia on Early Childhood Development. Diambil dari http://www.childencyclopedia.com/temperament/accordin g-experts/temperament-and-its-impactchild-development-comments-rothbartkagan. [diunduh 14 Agustus 2017].

Febriana. (2001). Pola pengasuhan, eq anak, dan faktor-faktor yang mempengaruhinya di SDN Kotamadya Bogor (Skripsi). Institut Pertanian Bogor, Bogor, Indonesia.

Gallagher, K. (2002). Does child temperament moderate the influence of parenting on adjustment?. Developmental Review, 22, 623-643.

Gentry, J. H., \& Campbell, M. (2002). A reference for professionals: developing adolescents. APA. Diambil dari https://www.apa.org/pi/families/resources /develop.pdf. [diunduh 27 Apr 2016].

Goleman, D. (2015). Kecerdasan emosional. Alih bahasa: Hermaya. Jakarta, ID: PT SUN.

Hooper, S. R., \& Umansky, W. (2009). Temperament and child development. Merrill, an imprint of Pearson Education Inc. Diambil dari http://www.education.com/reference/artic le/temperament-child-development/ [diunduh 10 Apr 2016].

Hurlock, E. B. (1999). Psikologi perkembangan: suatu pendekatan sepanjang ruang kehidupan. edisi 5 . Jakarta, ID: Erlangga.

Kim, I. J., Ge, X., Conger, R. D., Brody, G. H., \& Gibbons, F.X. (2003). Parenting behaviors and the occurrence and cooccurrence of depressive symptoms and conduct problems among African American children. Journal of Family Psychology, 17(4), 571-583.
Lange, A., Evers, A., Jansen, H., \& Dolan, C. (2002). PACHIQ-R: the parent-child interaction questionnaire-revised. Fam Proc., 41(4), 709-722. doi: 10.1111/j.1545-5300.2002.00709.x

Lestari, S. (2012). Psikologi keluarga: penanaman nilai dan penanganan konflik dalam keluarga. Jakarta, ID: Prenda Media Group.

Lerner, Jacqueline, V., Galambos, \& Nancy, L. (1985). Mother role satisfaction, motherchild interaction, and child temperament: A process model. Developmental Psychology, 21(6), 11571164. doi:10.1037/0012-1649.21.6.1157.

Leung, G. S. M., \& Ching, Y. K. (2011). Academic stressors and anxiety in children: the role of parental support. Presented at the Ninth Oxford Symposium in School-Based Family Counseling, Hong Kong: University of Hong Kong, June.

Luk-Fong, Y. Y. (2011). Globalization and localization: re-mapping school-based family counseling. Presented at the Ninth Oxford Symposium in School-Based Family Counseling, Hong Kong: University of Hong Kong, June.

Nasrudin. (2013). Hubungan fungsi afektif keluarga terhadap kecerdasan emosional remaja. Jurnal Eduhealth, 3(2), 89-96.

Papalia, D. E., Olds S. W., \& Feldman, R. D. (2009). Human development. New York, US: McGraw-Hill.

Prolap Inspektorat Kabupaten Bogor. (2015). Laporan kinerja 2014 pemerintah Kabupaten Bogor. Bogor, ID: Prolap Inspektorat Kabupaten Bogor

Putnam, S.P., Ellis, L.K., Rothbart, M.K. 2001. The structure of temperament from infancy through adolescence. Diambil dari

http://www.bowdoin.edu/ sputnam/rothb art-temperament-

questionnaires/pdf/Structure_of_Temp_fr m_Infancy_thru_Adolscn.pdf [diunduh 14 Feb 2016].

Puspitawati, H., \& Setioningsih, S. S. (2011). Fungsi pengasuhan dan interaksi dalam keluarga terhadap kualitas perkawinan dan kondisi anak pada keluarga tenaga kerja wanita. Jurnal IImu Keluarga dan Konsumen, 4(1), 11-20. doi: http://dx.doi.org/10.24156/jikk.2011.4.1.1 1. 
Rachmawati, M. (2015). Pengaruh sosialisasi emosi dan kecerdasan emosi terhadap perilaku agresi anak usia sekolah pada keluarga perdesaan (Skripsi). Institut Pertanian Bogor, Bogor, Indonesia.

Rueter, M., \& Conger, B. (1995). Interaction style, problem-solving behavior, and family problem-solving effectiveness. Child Development, 66(1), 98-115. doi:10.1111/j.1467-8624.1995.tb00858.x

Santrock, J W. (2007). Perkembangan anak, Ed 7, Jilid 2. Jakarta, ID: Erlangga. (2014). Adolescence, Ed 15 ${ }^{\text {th }}$. New York, US: McGraw-Hill Education.

Sari, I. P. (2011). Hubungan antara keberfungisan keluarga dengan kematangan emosi remaja laki-laki (Skripsi). Universitas Sumatera Utara, Medan, Indonesia.

Stoltzfus, J., \& Karraker, K. (2009). Goodness of fit between parenting style and child temperament: special challenges with slow-to-warm-up infants. in: handbook of parenting: styles, stresses \& strategies. New York, US: Nova Science Pub, Inc.
Sung, H. Y. (2008). Teachers' perspectives on change in student population and the need for emotional intelligence in education. Journal of Educational Practice for Social Change, 3(3). Diambil dari http://www.jepsc.org/archives.html. [Diunduh pada 15 Agustus 2017].

(2010). The influence of culture on parenting practices of East Asian families and emotional intelligence of older adolescents: a qualitative study. School Psychology International, 31(2), 199-214.

(2012). Nurturing emotional intelligence through a home-school partnership: Using teacher training as basis for school-based family counseling. International Journal for School-Based Family Counseling, 4, 1-10.

Ulutas, I., \& Omeroglu. (2008). Determining methods of mother support their children's emotion. Humanity \& Social Sciences Journal, 3(2), 151-157. 